\title{
Petunjuk bagi Penulis
}

Naskah. Naskah untuk publikasi Menara Perkebunan dapat berupa hasil penelitian atau ulasan (review). Naskah dapat ditulis dalam bahasa Indonesia maupun bahasa Inggris, disertai abstrak dalam dua bahasa tersebut. Diketik di atas kertas A4 dua spasi, setiap halaman diberi nomor urut. Judul dibuat singkat tidak lebih dari sepuluh kata. Di bawah judul dicantumkan judul dalam bahasa Indonesia atau bahasa Inggris, disertai nama penulis, instansi dan alamat penulis, diikuti abstrak. Naskah dikirim rangkap tiga dan soft file nya diserahkan kepada Dewan Penyunting disertai dengan surat pengantar dari penulis.

Abstrak. Terdiri atas abstrak bahasa Indonesia dan Inggris. Jumlah kata tidak lebih dari 250, memuat intisari dari seluruh tulisan yang meliputi tujuan, bahan dan metode, hasil dan kesimpulan.

Nama Ilmiah. Untuk penulisan pertama kali, nama ilmiah ditulis lengkap termasuk nama penemunya. Setelah itu dapat disingkat menjadi huruf awal. Jika menggunakan nama dalam bahasa Indonesia atau daerah, untuk pertama kali harus disertai nama ilmiah.

Penyingkatan. Istilah kimia yang panjang disingkat sesuai dengan ketentuan yang berlaku, misalnya DNA, RNA, ATP dst. Tanggal tidak boleh disingkat. Satuan ukuran ditulis lengkap kecuali, jika didahului angka misalnya g, mg, $\mathrm{mL}$. Penulisan jumlah dari nol sampai sepuluh ditulis dengan huruf kecuali yang diikuti oleh satuan ukuran ditulis dengan angka arab, misalnya 3 ton, $7 \mathrm{~mL}$, angka pecahan ditulis secara desimal.

Tabel, Gambar/Foto. Judul tabel/gambar/foto dibuat singkat dan jelas, ditulis dalam bahasa Indonesia dan Inggris. Judul tabel diletakkan di atas tabel, judul gambar/foto diletakkan di bawah gambar/foto yang bersangkutan.

\section{Contoh Cetak dan Cetak Lepas}

Contoh cetak dikirim kepada penulis untuk dibaca ulang dan disetujui terbit, dengan dibubuhi paraf untuk persetujuan cetak. Penulis akan mendapatkan lima cetak lepas naskahnya dengan cuma-cuma, dan satu eksemplar jurnal edisi tersebut.

Daftar Pustaka. Daftar pustaka disusun secara abjad ditulis memakai sistem CBE Council of Biology Editors 1994. Scientific Style and Format. Cambridge: Cambridge Univ. Publ. Judul jurnal yang diacu disingkat sesuai dengan World List of Scientific Periodicals. Beberapa contoh penulisan sumber acuan:

\section{Buku}

Tan KH (2003). Humic Matter in Soil and Environment. New York, Marcel Dekker.

Jurnal

Ahmad N, F Hassan \& G Qadir (2007). Effect of subsurface soil compaction and improvement measures on soil properties. Int J Agric \& Biol 9(3), 510-513.

\section{Bab dalam Buku}

Patrino GP \& W Ansorge-Oades (2005). Moleculer diagnostics: past. present, and future. In: Patrinos GP \& W Ansoerge (ed), Molecular Diagnostic. Amsterdam, Elsevier Academic Press. p. 1-12.

\section{Prosiding}

Solichin A \& JB Calvin (2007). Utilization of coal material for drying systems in crumb rubber processing. In: Proc Int Rubb Conf \& Exhibition. Bali, 13-15 June 2007 p, 265-269

\section{Informasi dari internet}

Dunford N (2002). ADM Launches Fat-Fighting Cooking Oil. Food \& Agricultural Products Center. December 17, 2002. Diunduh dari http://www.fapc. okstate.edu/FAPC-Flash/newcooking oil.pdf. [21 Juli, 2009] 